Wilfrid Laurier University

Scholars Commons @ Laurier

$5-1-2002$

\title{
Environmental Change, Protest, and Havens of Environmental Degradation: Evidence from Asia
}

Derek Hall

Wilfrid Laurier University, dehall@wlu.ca

Follow this and additional works at: https://scholars.wlu.ca/poli_faculty

\section{Recommended Citation}

Hall, Derek, "Environmental Change, Protest, and Havens of Environmental Degradation: Evidence from Asia" (2002). Political Science Faculty Publications. 7.

https://scholars.wlu.ca/poli_faculty/7

This Article is brought to you for free and open access by the Political Science at Scholars Commons @ Laurier. It has been accepted for inclusion in Political Science Faculty Publications by an authorized administrator of Scholars Commons@Laurier. For more information, please contact scholarscommons@wlu.ca. 


\section{Environmental Change, Protest, and Havens of Environmental Degradation: Evidence from Asia}

Derek Hall*

As has been made clear by the other contributions to this debate, much of one's analysis of the question of "pollution havens" depends upon how one frames the question. While I do not wish to repeat the arguments that have been made by the preceding authors, I would like to suggest that it is useful to characterize the literature in economics on pollution havens in terms of its choices among two independent variables and three dependent variables. In seeking to identify which environmental factors might influence the global economy, scholars have generally focused on either expenditures on pollution abatement or on the relative "dirtiness" of different industries (generally measured in terms of toxic emissions). In order to determine the effects of these causal factors, most authors have examined intercountry differences in industrial structure, trade flows, and foreign direct investment (FDI). It is thus possible to place much of the literature within a $2 \times 3$ grid based on the choices made within this menu of independent and dependent variables. Lucas, Wheeler, and Hettige, for instance, have studied the effect of toxic emissions on industrial structure, while Tobey has investigated the effects of environmental compliance costs on patterns of trade. $^{1}$

It is important to recognize, however, that the questions posed within this grid do not exhaust the research questions that are relevant to the study of pollution havens. A broader framing of the question underlying the debate might go as follows: to what extent do the environmental transformations associated with particular sectors influence their international siting patterns? Posing the question in this way would move the debate away from the questions of intentionality and regulatory costs addressed in this issue by David Wheeler (while still, of course, encompassing them) and towards the consequences, anticipated and otherwise, of environmental degradation. This article attempts to

* I am grateful to Jennifer Clapp, Megan Thomas, and two anonymous reviewers for their suggestions.

1. Lucas, Wheeler, and Hettige 1992; and Tobey 1990. My characterization of the literature differs slightly from that of Neumayer 2001, 149. 
address new aspects of this broader question by departing from the existing literature in two ways. First, I address the consequences for international siting patterns of another aspect of environmental transformations: environmentallyoriented protest. While protest often results in tightened regulatory conditions, it also affects firms by creating non-regulatory difficulties in the actual siting and construction of plants and by generating uncertainty about future regulation. The connections between environmentally-oriented protest and the actual environmental problems caused by different sectors are not, of course, air-tight; it is possible that protesters are in fact mistaken about the environmental degradation that they perceive industry to be causing. In this article, I will not address this question, other than to note that a similar association of protest with environmental damage is made in much of the pollution havens literature in economics. $^{2}$

Second, while most studies of pollution havens have taken aggregate statistics to be the relevant data in the determination of what drives siting decisions, I take a more phenomenological approach by examining the actual statements of firm representatives. The cases I examine provide examples of firms indicating that headaches over environmental protest are a primary factor in motivating their FDI. I attempt to advance this more political and phenomenological study through an analysis of two cases in the political economy of Japan's relations with Southeast Asia. The first case takes up the possibility that Japan's FDI to Southeast Asia during the 1970s was motivated in part by the desire (on the part of both firms and the Japanese state) to escape from antipollution protest in Japan. The second asks whether the siting of overseas industrial tree plantations (particularly plantations of the species Eucalyptus camaldulensis) supplying the Japanese market for wood chips and paper pulp has been influenced by the environmental problems those plantations cause. These cases present useful contrasts for the study of pollution export, varying as they do in time (the 1970s for manufacturing FDI, the 1980s and 1990s for plantation forestry), sector (manufacturing vs. forestry), and the location of protest (Japan vs. Southeast Asia). However, they are similar in that each case has seen protest against environmental problems and clear statements by firms that the desire to escape that protest was influencing their siting decisions. While the first case seems to be a fairly straightforward example of firms searching for pollution havens, the second requires more interpretation and indeed presents a somewhat counterintuitive result.

\section{"Pollution Export" from Japan during the 1970s}

Japanese industrialization during the 25 years after World War II was based on the extremely rapid expansion of heavy and chemical industry with little or no attention to pollution control. Given the location of much of this industry in 
densely populated areas, it is not surprising that by the mid-1960s the country was facing an environmental crisis of frightening dimensions. ${ }^{3}$ The political side of this crisis manifested itself at the national level, with increasing public concern over pollution putting intense pressure on the ruling Liberal Democratic Party (LDP) and challenging the consensus over high-speed growth, and at the grassroots in terms of a remarkable flowering of movements opposing local pollution. By the late 1960s, this wave of protest was prompting government and business to consider new patterns of industrial siting both domestically and internationally. The fact that these considerations coincided with a rapid increase in Japan's FDI in resource-and pollution-intensive projects has led many observers to assume that the former helped to cause the latter, but little careful study of this issue has been done.

A consideration of the oil refining and petrochemicals industries suggests that there is reason to accept the argument. These industries were among those facing particularly intense protest in Japan at the turn of the 1970s, and also saw a roughly contemporaneous rapid upturn in FDI projects, particularly to Asia. While there were various factors pushing the overseas relocation of parts of the Japanese petrochemical industry (particularly after the 1973 oil shock), statements by both business and government make it clear that the desire to escape anti-pollution protest was a primary cause of the FDI boom. On the government side, the Ministry of International Trade and Industry (MITI) announced in June 1970 that it would be establishing a fund to assist the movement of the petrochemicals industry overseas, and in particular to Southeast Asia. One of the three reasons cited by MITI for this move was that pollution was making the establishment of petrochemical facilities more and more difficult. ${ }^{4}$ These difficulties were also made clear in the industry's attitude to overseas relocation, both at an industry-wide level and at the level of individual firms. The Kagaku Keizai Kenkyûjo (Chemicals Economic Research Institute) stressed in a 1972 report both that domestic protest against the industry was the major reason for overseas projects and that MITI was encouraging the future overseas movement of the sector. ${ }^{5}$ On the latter issue, the report argued that "this is the first time MITI has genuinely emphasized the necessity of overseas siting for key resourcetype industries, and should be seen as an epoch-making move by MITI in response to environmental problems. "6 It should be noted that the problems facing domestic petrochemical production were phrased almost entirely in terms of oppositional citizens' movements rather than tightening regulatory standards.

Some sense of the domestic problems facing individual firms may be gained from an examination of Mitsubishi Oil's efforts to construct an oil refinery. The company's original plan envisaged building the refinery in Chiba

3. Broadbent 1998.

4. Nikkan Kôgyô Shinbun, June 201970.

5. Kagaku Keizai Kenkyûjo 1972, 24, 27-8.

6. Ibid., 23. 
Prefecture (near Tokyo), but intense local opposition caused the company to abandon the plan and to shift its attention to Shibushi Bay in Kagoshima Prefecture, southern Japan. However, intensifying opposition there prompted Mitsubishi in 1972 to announce an effort to move some of the project to Kin Bay in Okinawa. ${ }^{7}$ In July 1970, meanwhile, Mitsubishi announced its desire to establish an oil refinery in Southeast Asia, in part because opposition to air and water pollution in Japan had made finding a suitable site "extremely difficult" (kiwamete muzukashii). Interestingly, the plan was criticized on economic grounds as unlikely to yield a profit, but Mitsubishi felt that it had no choice given opposition in Japan. ${ }^{8}$ Mitsubishi subsequently became involved in largescale overseas petrochemical projects in Singapore and Thailand. Citizen protest was thus pushing Mitsubishi Oil's siting decisions to shift towards increasingly peripheral (and politically weak) regions of Japan and to Southeast Asia.

Oil refining and petrochemicals were far from the only sectors to face these problems; similar difficulties confronted, and were explicitly acknowledged by, firms in aluminum refining, zinc, steel, and oil storage, among other industries. ${ }^{9}$ It is also notable that foreign governments, including those of Peru, South Korea, and the Philippines, appealed to Japan to relocate some of its highly-polluting industrial plant to their countries. The documentary evidence makes it clear that in the early 1970s, Japanese businessmen in pollutionintensive sectors saw anti-pollution protest as a key reason to relocate to Asia. At the same time Japanese politicians and bureaucrats were developing policy measures to assist this process and Asian leaders welcomed the relocation.

\section{Industrial Tree Plantations in Southeast Asia}

The industrial tree plantation (ITP) sector provides a good example of the kind of non-manufacturing sector which, as Jennifer Clapp has argued in this issue, has not been addressed in the pollution havens debate despite being relevant to it. ITPs have, over the last 20 years, become a popular response to the scarcity of natural forest resources. As both tightened regulation and increasing absolute scarcity have created problems for forestry companies worldwide, more and more states and firms have turned to planting their own trees in an effort to secure homogenous and reliable sources of supply. ITPs are established more or less along the lines of industrial farming, relying as they do on "intensive preparation of the soil, fertilisation, regular spacing of trees, seedling selection, intensive weeding using machines or herbicides, use of pesticides, thinning, mechanised harvesting, and in some cases, pruning." 10 While the agro-industrial character of these fast-growing plantations has endeared them to paper compa-

7. Nikkan Kôgyô Shinbun, February 221972.

8. Nikkan Kôgyô Shinbun, July 181970.

9. See, respectively, Nikkan Kôgyô Shinbun, December 5 1971; Nikkan Kôgyô Shinbun, May 31 1971; Nihon Bengoshi Rengôkai 1991; and Sotoyama 1977.

10. Carrere and Lohmann 1996, 4. 
nies, the changes wrought by tree plantations on surrounding environments have led to political conflict over environmental degradation around the world. Despite the fact that the environmental consequences of ITPs are not captured by toxic release inventories, these consequences have had important implications for siting patterns.

The clearest environmental problem caused by ITPs is their impact on hydrological cycles. Tree plantations have quite different ratios of water intercepted by foliage to that reaching the ground, of runoff to water infiltrating the soil, and of evapotranspiration to water reaching the subsoil than do mixed forests. ${ }^{11}$ Eucalypts (popular in Southeast Asian ITPs), in addition, absorb water from much further underground than do other trees and plants. Plantations thus unbalance water cycles, with results including reduced water flow throughout the year, the disappearance of streams during the dry season, and damage to other ecosystems facing reduced access to water. These environmental changes create obvious difficulties for local farming and have been responsible for a good deal of the resistance to ITPs. Less obvious but more important are the consequences of the environmental transformations undertaken in the establishment of ITPs. Although the clearing of natural forest has had catastrophic results around the world, loggers have not generally needed close control over forest land before they actually came to log it, and after logging it has often been possible for local people to expand farming. Tree plantations are very different in that the creation and maintenance of an artificial ecosystem requires long-term, intensive control over land. In many developing countries, much of the area which has been marked out for tree plantations is subject to uncertain tenure and conflicting use claims of locals and the state. ITP establishment has thus often led to the denial of forest resources (such as wild plants or grazing areas) to local people or to outright coercion and intimidation in land acquisition. Responses to the arrival of ITPs and the environmental changes that accompany them have included organized resistance and even violence.

ITPs now play a central role in supplying the Japanese market, and the Japanese pulp and paper industry has had to confront the problems outlined above in its efforts to site tree plantations overseas. The industry has been interested in the establishment of overseas tree plantations to meet Japanese demand since the 1971 formation of the Nanpô Zôrin Kyôkai (Southern Afforestation Association), which set up experimental plantations in Malaysia, Indonesia, Papua New Guinea, and the Solomon Islands during the 1970s and saw Southeast Asia as the most promising future location for tree plantations. ${ }^{12}$ While interest in overseas plantations waned during the early 1980s, by the end of that decade the booming Japanese paper market and the increased value of the yen led to renewed enthusiasm. Industry participants also stress that in the 1980s Japanese paper companies realized that tightening regulation of forestry in the United

11. Ibid., 64-5.

12. Hisada 2000, 22. 
States and Canada meant that they would have to look elsewhere for resources-a clear case of international location decisions being motivated in part by environmental regulation. ${ }^{13}$ From 1989, Japanese companies began setting up plantations overseas as the paper industry announced a commitment to source $1 / 3$ of its wood chip consumption from foreign plantations by $2010 .{ }^{14}$ By 2000, Japanese companies had established 257,600 ha of tree plantations abroad. However, only one of these was set up in Southeast Asia (Vietnam); new projects were concentrated in Australia (13 cases), Chile (3), and New Zealand (2). ${ }^{15}$

This pattern is surprising not only because of previous Japanese interest in Southeast Asia as a location for fast-growing tree plantations, but also because Thailand and Indonesia both embarked during the 1980s on extremely ambitious projects for the establishment of ITPs, projects which were inspired in part by the Japanese paper market. However, in Thailand in particular, antieucalyptus protest has been a major factor in hindering both FDI and domestic investment in the sector. Northeastern Thailand, for instance, saw widespread resistance to plantations in the mid-1980s and early 1990s. By 1992 the government had cancelled a highly militarized plan to relocate 250,000 families in the northeast to make way for eucalyptus plantations, and had imposed restrictions on the development of large-scale ITPs. During this period, several Japanese or Japan-oriented plantation projects fell victim to protest and political uncertainty, including a Shell project which would have exported 900,000 tons of wood chips to Japan annually. ${ }^{16}$ Thai companies have responded to difficult political and regulatory conditions by moving into neighboring countries such as Laos. $^{17}$

Japanese companies interested in setting up overseas ITPs have increasingly recognized the problems that these efforts face in developing countries, and have reoriented their investment to Australia in particular. This change in strategy was articulated by industry figures who complained of the difficulties faced in developing countries in securing long-term access to land resources. ${ }^{18}$ It is also reflected in the 1998 reorganization (with MITI and MAFF support) of the Nanpô Zôrin Kyôkai into the Kaigai Sangyô Shokurin Sentâ (Japan Overseas Plantation Center for Plywood), with the conscious change in emphasis from Southeast Asia to the globe made explicit in the change of name. ${ }^{19}$ What should be stressed here is that the difficulties in gaining access to land noted by industry sources result not only from the evictions and harassment that frequently accompany the establishment of industrial tree plantations, but also from the environmental changes-the elimination of access to forest products, and the

13. Morimoto 1993,44 .

14. Hisada $2000,23$.

15. Figures from unpublished data, Kaigai Sangyô Shokurin Sentâ 2000.

16. Tasaka 1992, 111-115.

17. Watershed 1998-9.

18. Morimoto 1993, 45.

19. Wakano 1998. 
depletion of water supplies - that plantations bring about. Ironically, however, the result of the protest against the environmental transformations caused by ITPs has been the relocation of the sector away from countries like Thailand and Indonesia and toward Australia. It appears that, in Australia, the greater security of tenure (making it easier for Japanese companies to reliably affect the environmental changes they require in order to run an ITP) and the lower population density around ITPs (thus reducing protest over water issues) has facilitated ITP establishment.

The implications of this case for the pollution havens literature thus depend upon the way the question of pollution havens is framed. With respect to the question of whether environmental protest is driving economic activity from developed to developing countries, this case represents not merely a negative finding but in fact a finding that runs directly contrary to the expectation: Japanese companies have here shifted their attention from a less-developed country to a more-developed one. The reasons for this shift, however, including as they do the political consequences of the environmental changes brought about by ITPs, fall squarely within the range of the questions asked at the beginning of this article.

\section{Conclusions}

While it is impossible to draw any conclusions for the global study of pollution havens on the basis of two cases, the analysis presented above raises a number of interesting issues for the future development of the literature. First, the case of Japanese FDI in the 1970s makes it clear that pollution export can be a state strategy. The Japanese government was explicitly funding the transfer of "dirty" industries abroad. Second, case studies can illuminate aspects of the impact of environmental problems on siting decisions that are missed by large-n studies. The disruption of hydrological cycles caused by large-scale industrial tree plantations and the problems it engenders for local agriculture, for instance, would not be visible to a methodology focusing on toxic release. Third, while the pollution havens literature has generally sought to determine the causes of siting decisions through regression analysis, my research in both of these cases has revealed a wealth of examples (only some of which can be presented here) of industry representatives explicitly stating that the desire to escape environmental protest is one of their major motivations.

It may be, however, that the relative abundance of these statements in the sectors I address is a result of special characteristics of the cases. With regard to ITPs, much of the local resistance to their establishment has been conceptualized as conflict over land rather than being, as I have argued, related to the environmental transformations these plantations bring about. Corporate spokesmen have thus discussed their location decisions largely in these terms rather than as an escape from environmental protest. In Japan in the early 1970s, on the other hand, no major stigma attached to firms stating that they were relocat- 
ing overseas to escape anti-pollution protest; in some cases, firms presented these actions as demonstrations of their new commitment not to pollute at home. Indeed, the frankness with which Japanese firms of the early 1970s were prepared to admit that they were relocating overseas in order to escape domestic protest is, in retrospect, quite striking. This frankness may be explained in part by the fact that journalistic interest in Japan's "pollution export" did not begin until 1972 and organized opposition only commenced in 1973; by 1974-5, Japan had an active and well-publicized citizens' movement opposing the export of pollution. While the public prominence of this movement likely led firms and government agencies to become much more circumspect in their public statements by the mid-1970s, the prior period provides an interesting example of firms publicly discussing their siting debates without fear of political consequences. In both of the cases I have addressed here, then, special circumstances made firms less reticent than they might otherwise have been to state that their siting decisions were based in part on environmental protest. It may be that the difficulty of obtaining this kind of evidence in more "normal" cases will render this intentional approach to the study of pollution havens of limited value. It is also possible, of course, that in the absence of a concern for bad press, more such statements would be made.

\section{References}

Broadbent, Jeffrey. 1998. Environmental Politics in Japan: Networks of Power and Protest. Cambridge: Cambridge University Press.

Carrere, Ricardo, and Larry Lohmann. 1996. Pulping the South: Industrial Tree Plantations and the World Paper Economy. London: Zed Books.

Hisada, Mutsuaki. 2000. Wagakuni Minkan Kigyô no Kaigai Sangyô Shokurin no Dôkô (Trends in our Country's Private Overseas Industrial Tree Planting). Kokusai Nôringyô Kyôryoku (International Agriculture and Forestry Cooperation) 22: 18-28.

Kagaku Keizai Kenkyûjo. 1972. Showa 47-nendo Kagaku Kôgyô Sôgô Chôsa (1972 General Survey of the Chemical Industry). Tokyo: Kagaku Keizai Kenkyûjo.

Kaigai Sangyô Shokurin Senta. 2000. Unpublished Data. Revised June 2002.

Leonard, H. Jeffrey. 1988. Pollution and the Struggle for the World Product: Multinational Corporations, Environment, and International Comparative Advantage. Cambridge: Cambridge University Press.

Lucas, Robert E. B., David Wheeler, and Hemamala Hettige. 1992. Economic Development, Environmental Regulation and the International Migration of Toxic Industrial Pollution: 1960-88. In International Trade and the Environment, edited by P. Low, 67-86. Washington, DC: World Bank.

Morimoto, Taiji. 1993. Parupuzai no Shôrai Tenbô (Future Direction of Pulp Materials). Kamipa Gikyôshi (Paper-Pulp Technical Cooperation) 47: 35-47.

Neumayer, Eric. 2001. Pollution Havens: An Analysis of Policy Options for Dealing with an Elusive Phenomenon. Journal of Environment and Development 10: 147-77.

Nihon Bengoshi Rengôkai. 1991. Nihon no Kôgai Yushutsu to Kankyô Hakai: Tônan Ajia ni Okeru Kigyô Shinshutsu to ODA (Japan's Pollution Exports and Environmental Destruction: The Advance of Companies and ODA into Southeast Asia). Tokyo: Nihon Hyôronsha. 
Sotoyama, Tetsu. 1977. Parao CTS Keikaku to wa nani ka (What is the Palau CTS Plan?). Jishu Kôza (Independent Forum) 76: 8-9.

Tasaka, Toshio. 1992. Yûkari Bijinesu: Tai Shinrin Hakai to Nihon (Eucalyptus Business: Japan and Forest Destruction in Thailand). Tokyo: Shin Nihon Shuppansha.

Tobey, James A. 1990. The Effects of Domestic Environmental Policies on Patterns of World Trade: An Empirical Test. Kyklos 43: 191-209.

Wakano, Tadao. 1998. Kaigai Sangyô Shokurin Sentâ no Hossoku ni tsuite (On the Establishment of the Japan Overseas Plantation Center for Pulpwood). Kami Parupu (Paper Pulp): 1-6. 